\title{
Elimination of Turbidity Interference in Serum Iron Colorimetric Assay by Enzymatic Proteolysis
}

\author{
Leonardo M. Cardoso*, Milton H. G. de Andrade ${ }^{1}$, Deoclécio A. Chianca Junior ${ }^{1}$, Marcelo \\ Eustáquio Silva ${ }^{2}$ and Maria Lúcia Pedrosa ${ }^{1}$ \\ ${ }^{I}$ Depto de Ciências Biológicas; Núcleo de Pesquisa em Ciências Biológicas; ICEB; Universidade Federal de Ouro \\ Preto; 35400-000; Ouro Preto - Minas Gerais - Brazil. ${ }^{2}$ Depto de Alimentos; Escola de Nutrição; Universidade \\ Federal de Ouro Preto; 35400-000; Ouro Preto - Minas Gerais - Brazil
}

\begin{abstract}
We describe a modification in the commercial colorimetric method for the determination of serum iron by using Ferrozine $^{\circledR}$. The modification was proposed because during the conventional procedure, turbidity observed when the serum of animals submitted to surgery was used interfered with the assay. We added to the original method, a previous treatment of the serum with proteolytic enzymes. This modification was also tested using plasma samples, although this was not recommended when the original method was used. The results demonstrated that: a) the treatment with a mixture of trypsin and chymotrypsin was effective in order to eliminate turbidity; b) there was no difference between the standard curves obtained by the conventional and the modified method for control assays; c) the absorbencies of the samples of serum and plasma submitted to proteolysis, estimated by the addition of different concentrations of iron, were directly proportional to iron concentrations; d) the pre-treatment with enzymes allowed the utilization of plasma; e) the pre-treatment with guanidine. HCl was not effective.
\end{abstract}

Key words: Iron assay, enzymatic proteolysis, interference

\section{INTRODUCTION}

The Ferrozine ${ }^{\circledR}$ dye-binding method, performed without prior deproteinization is largely used to determine the iron concentration in serum samples. Although extensively used both in clinical and research laboratories, factors such as lyphemia, hemolysis (Valcour et al., 1990), and the presence of anti-coagulant in samples (Bothwell et al., 1979) interfere with the reaction. Turbidity, resulting from precipitation of fibrinogen, has also been described in samples from hemodialysis patients (Ooi et al., 1992). In evaluating the circulating iron levels in laboratory rats submitted to surgical trauma, turbidity was observed in the reaction medium, making the dosage impossible. The phenomenon was observed in anticoagulant free samples but it was more intense when heparin was given to the animals during the surgical process.

In the present study we used enzymatic proteolysis of plasma and serum samples and compared the results to those obtained with commercially available kits.

\section{MATERIAL AND METHODS}

Materials: Commercial colorimetric kits for serum iron determination were obtained from

\footnotetext{
* Author for correspondence
} 
Labtest Diagnostica S.A. and Bioclin Química Básica (Belo Horizonte, MG, Brazil). Both contain buffer $250 \mathrm{mmol} / \mathrm{L}, \mathrm{pH} 4.0$ with hydroxylamine $144 \mathrm{mmol} / \mathrm{L}$; iron standard solution $100 \mu \mathrm{g} / \mathrm{dL}$ and Ferrozine $^{\circledR} 28 \mathrm{mmol} / \mathrm{L}$. Porcine trypsin (activity: 1,870 units N $\alpha$-Benzoyl-L-arginine Ethyl Ester/mg) and bovine chymotrypsin (52 units NBenzoyl-L-tyrosine Ethyl Ester/mg protein),

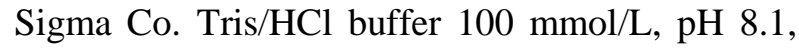
containing Tris (hydroxymethil) aminomethane, Sigma Co. and $\mathrm{HCl} 100 \mathrm{mmol} / \mathrm{L}$ (Merck S.A). Guanidine. $\mathrm{HCl}$ was obtained from Merck S.A.

Samples: Serum or plasma samples were obtained from male Fisher rats from three different groups: 1 - Serum from five cannulated animals (CA serum): Under anesthesia with $25 \mathrm{mg} / \mathrm{Kg} 2,2,2$ tribromoethanol (Aldrich Chemical Company, Inc. Milwaukee, WI USA), a cannula was inserted into the abdominal aorta through the femoral artery for measurement of pulsate arterial pressure. A second cannula was inserted into femoral vein for drug administration (Chianca-Jr and Machado, 1994). Twenty four hours after surgery, the blood was collected through the cannula inserted in the abdominal aorta, in a glass syringe and transferred to polyethylene tubes. After 15 minutes, the blood was centrifuged at $14,000 \mathrm{rpm}$ for $8 \mathrm{~min}$ in an Eppendorf 5410 microcentrifuge. The serum was then separated, recentrifuged under the same conditions for the removal of the remaining cells and pooled;

2 - Serum samples of 9 non-cannulated animals (NCA serum): Before blood collection, these animals were anesthetized with $25 \mathrm{mg} / \mathrm{Kg}$ 2,2,2 tribromoethanol (Aldrich Chemical Company, Inc. Milwaukee, WI USA). The aorta artery was exposed and sectioned and the blood was placed in a glass tube. After 15 minutes, the blood was centrifuged at 3,000 rpm in an Excelsa Baby 206 model centrifuge (Fanem), for 10 minutes. The serum was separated, placed in polyethylene tubes and centrifuged at $14,000 \mathrm{rpm}$ for $8 \mathrm{~min}$ in an Eppendorf centrifuge and subsequently pooled; 3 - Plasma of 9 cannulated animals (CA plasma): The animals received $20 \mu \mathrm{g}$ of heparin in the systemic circulation $24 \mathrm{~h}$ after the surgical trauma and 90 minutes before the blood collection. The blood was collected through the cannula inserted in the abdominal aorta in a glass syringe, and transferred to polyethylene tubes. After fifteen minutes, the blood was centrifuged at $14,000 \mathrm{rpm}$ for $8 \mathrm{~min}$ in an Eppendorf 5410 microcentrifuge. The plasma was then separated, recentrifuged under the same conditions for the removal of the remaining cells and pooled. All samples were stored at $4^{\circ} \mathrm{C}$ and assayed within 6 days.

Principle: Ferric iron is dissociated from transferrin in an acid buffer $(\mathrm{pH} 4.0,250 \mathrm{mmol} / \mathrm{L})$ and it is reduced to ferrous state by hydroxylamine. The ferrous ion forms a colored complex with Ferrozine ${ }^{\circledR}$ [3-(2-pyridyl)-5,6-bis (4phenyl-sulfonic acid)-1,2,4triazine; $\left.A_{\max } 560 \mathrm{~nm}\right]$ with an absorbance that is proportional to the concentration of iron in the sample (Stookey, 1970).

Control assay - auxiliary absorbance $\left(A_{1}\right)$ and final absorbance $\left(\mathbf{A}_{\mathbf{2}}\right)$ : Pool serum or plasma, 250 $\mu \mathrm{L}$; water, $40 \mu \mathrm{L}$; Tris/HCL buffer $100 \mathrm{mmol} / \mathrm{L}$, $\mathrm{pH} 8.1,200 \mu \mathrm{L}$ were dispensed into tubes, mixed and incubated for $2 \mathrm{~h}$ at $37^{\circ} \mathrm{C}$. After addition of $1000 \mu \mathrm{L}$ of kit's buffer the absorbance of the mixture and standard $(250 \mu \mathrm{L}$ of iron standard solution $100 \mu \mathrm{g} / \mathrm{dL}$ ) were measured against blank $(250 \mu \mathrm{L}$ of water) at $560 \mathrm{~nm}$. This reading was referred as absorbance $\mathrm{A}_{1}$. Then, $30 \mu \mathrm{L}$ of ferrozine were added, mixed and incubated for 10 $\min$ at $37^{\circ} \mathrm{C}$. The absorbance of sample and standard were read against blank at $560 \mathrm{~nm}$ (absorbance $\mathrm{A}_{2}$ ). Iron concentration was calculated from the difference between $\mathrm{A}_{2}$ and $\mathrm{A}_{1}$.

Proteolysis assay: In order to avoid precipitation, proteolytic treatment was carried in samples before addition of kit's buffer. $40 \mu \mathrm{L}$ of a protease solution $(60 \mathrm{mg} / \mathrm{mL}$ of trypsin and chymotrypsin prepared in distilled water) was mixed to $250 \mu \mathrm{L}$ of sample (serum or plasma) plus $200 \mu \mathrm{L}$ of Tris/HCL buffer $100 \mathrm{mmol} / \mathrm{L}, \mathrm{pH}$ 8.1. The mixture was incubated for $2 \mathrm{~h}$ at $37^{\circ} \mathrm{C}$. A blank and an iron standard were prepared in the same way. After this incubation the assay proceeded as described above. To measure the effect of this treatment on the performance of the assay, a standard curve was prepared by adding known concentrations of iron to a serum or plasma sample $(0 \mu \mathrm{g} / \mathrm{dL}, 25 \mu \mathrm{g} / \mathrm{dL}$, $50 \mu \mathrm{g} / \mathrm{dL}, 75 \mu \mathrm{g} / \mathrm{dL}$ and $100 \mu \mathrm{g} / \mathrm{dL})$. These samples were then assayed with or without the proteolytic treatment and the results compared. 
Guanidine assay: Guanidine was added to the kit's buffer in order to achieve a final concentration of $1.6 \mathrm{~mol} / \mathrm{L}$ in the reaction mixture. To $250 \mu \mathrm{L}$ of plasma or serum, $1000 \mu \mathrm{L}$ of guanidine-containing buffer and $240 \mu \mathrm{L}$ of water were added. After 20 minutes incubation at $20^{\circ} \mathrm{C}$ the tubes were centrifuged at $14,000 \mathrm{rpm}$ for 15 min. A second set of tubes was prepared as described, except for the fact that the samples were incubated at $37^{\circ} \mathrm{C}$ for 20 minutes after the addition of the guanidine buffer. The supernatants were used for the determination of $A_{1}$ and $A_{2}$ as described before. Standard curves similar to the ones described for the proteolytic treatment were prepared for this treatment.

Absorbance spectrum: This was performed with the products from the assays with the non cannulated animal serum samples submitted to proteolysis and control assays. Both were submitted to screenings between 360 and $800 \mathrm{~nm}$, in a Shimadzu UV-1601 spectrophotometer.

\section{Calculations:}

I - Iron concentration taken from the assay standard and sample absorbance:

$$
[F e]=\left(\frac{\Delta A}{A_{S}}\right) \times 100 \mu g / d L=\mu g / d L
$$

Where:

$[\mathrm{Fe}]=$ iron concentration

$\Delta A=\mathrm{A}_{2}-\mathrm{A}_{1}$

$A_{s}=$ standard absorbance at $560 \mathrm{~nm}$.

II - Iron recovery:

$$
R \%=\left[\left([\mathrm{Fe}]-[\mathrm{Fe}]_{0}\right) /[\mathrm{Fe}]_{e}\right] \times 100
$$

Where:

$R \%=$ percentage of iron recovered;

$[\mathrm{Fe}]=$ iron concentration in the sample with addition of iron standard solution, calculated from the absorbance;

$[\mathrm{Fe}]_{0}=$ iron concentration in the sample without addition of iron standard solution, calculated from the absorbance;

$[\mathrm{Fe}]_{e}=$ expected iron concentration in each sample of serum and plasma.
Statistical analysis: Statistical analysis was performed by variance analysis (ANOVA) and results are shown as mean \pm standard deviation.

\section{RESULTS}

Preliminary observations from our laboratory showed that the utilization of commercially available kits for iron determination with serum from cannulated animals (CA) resulted in the development of turbidity in the reaction tube that interfered with the assay (data not shown). Assay of serum and plasma samples from CA showed turbidity in the reaction medium right after the addition of the iron dissociating buffer. Plasma samples showed more intense turbidity in the final result $\left(\mathrm{A}_{2}\right)$ than serum samples. This phenomenon was not observed in the serum from non cannulated animals (NCA)

Auxiliary absorbance $\left(\mathbf{A}_{1}\right)$ : Samples from CA serum, right after the acid buffer addition, showed significant turbidity in the reaction resulting in high values of auxiliary absorbance $\left(\mathrm{A}_{1}\right)$. In contrast, samples of the same serum treated with enzymes showed lower values for $A_{1}$. The values were $0.143 \pm 0.006$ for the control assay and 0.006 \pm 0.001 for the enzymes treated one (fig 1). With serum samples from NCA, the control assays showed relatively high values for $\mathrm{A}_{1}$ (fig 1 ) when compared to the ones in which the proteolysis was performed: $0.023 \pm 0.001$ and $0.003 \pm 0.001$, respectively. Turbidity was noted in plasma samples submitted to the control assay after the addition of the iron dissociating buffer, while no detectable turbidity was noted in treated samples: $0.071 \pm 0.006$ and $0.004 \pm 0.002$, respectively) as shown in figure 1 . Thus, treatment of serum or plasma samples with proteolytic enzymes significantly decreases the absorbance values for $\mathrm{A}_{1}$. 


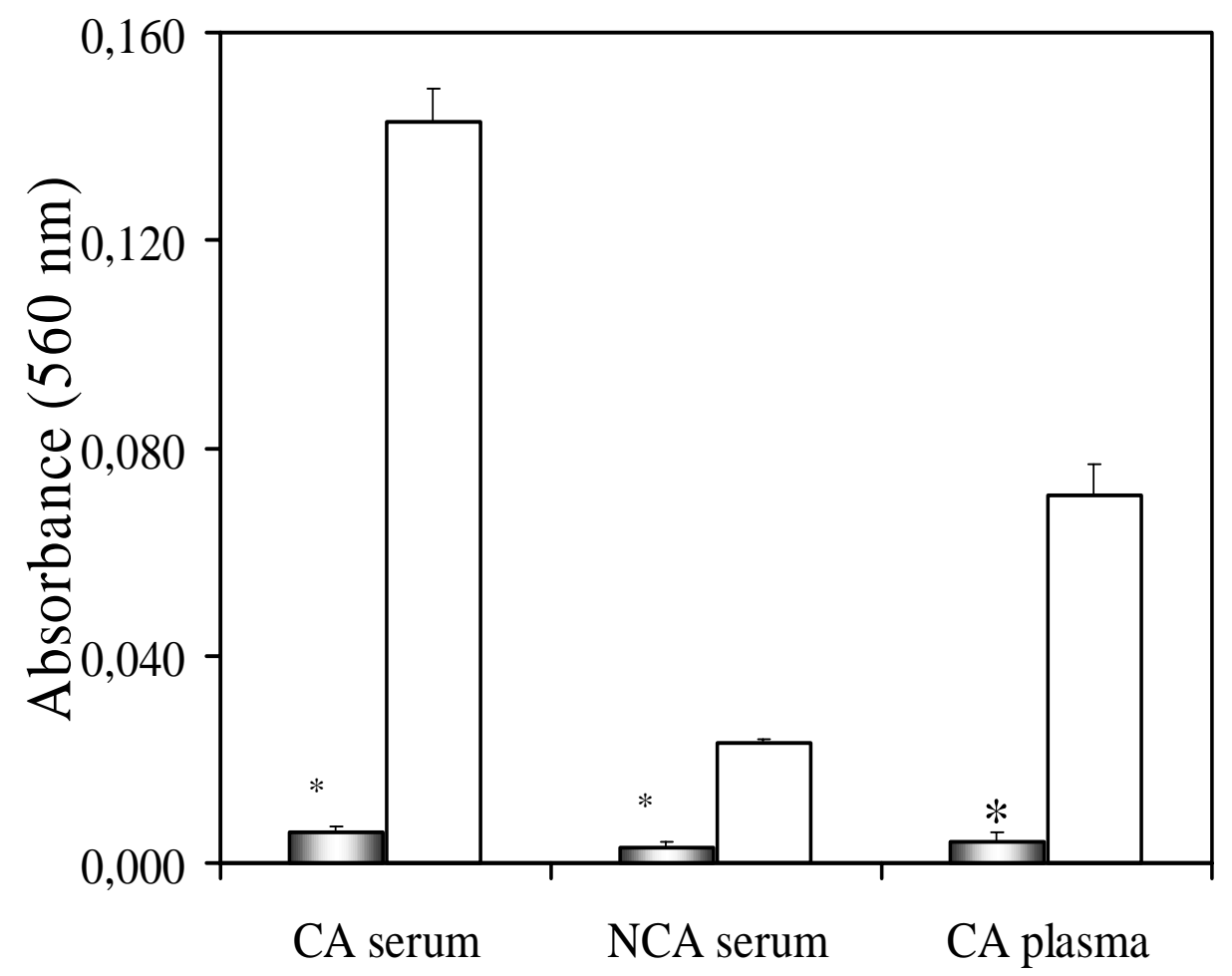

Figure 1 - Auxiliary absorbance at $560 \mathrm{~nm}$, without ferrozine ${ }^{\circledR},\left(\mathrm{A}_{1}\right)$ for serum samples from cannulated animals (CA serum), serum samples from non cannulated animals (NCA serum) and cannulated animals plasma (CA Plasma); gray columns show the mean $\pm \mathrm{SD}(\mathrm{n}=5)$ of assays with proteolytic treatment and the white ones show the mean \pm SD $(n=5)$ for control assays; significant differences in relation to the control assay: $* \mathrm{P}<0,05$ (ANOVA).

Standard curves: Serum samples generated linear curves in the iron concentration range interval used in the experiments. Nevertheless, some differences were noticed in the behavior of these samples in the assay. Fig 2 shows the iron standard curves from CA serum samples. The absorption coefficient in the assays with proteolysis was slightly lower than the control: $1.6 \times 10^{-3}(\mu \mathrm{g} / \mathrm{dL})^{-}$ ${ }^{1} \times \mathrm{cm}^{-1}$ and $1.8 \times 10^{-3}(\mu \mathrm{g} / \mathrm{dL})^{-1} \times \mathrm{cm}^{-1}$, respectively.

Fig 3 shows the standard curves from NCA serum samples where there was no significant difference between the curves from control and proteolysis assays. Regarding the plasma samples (figure 4), without proteolysis the turbidity is increased after ferrozine addition and incubation for 10 minutes at $37^{\circ} \mathrm{C}$. The differences were evident concerning the absorption coefficient, 2.6 times higher in the proteolysis assay compared to the control assay, respectively $3.6 \times 10^{-3}$ and $1.4 \times 10^{-3}(\mu \mathrm{g} / \mathrm{dL})^{-1} \times \mathrm{cm}^{-1}$. On the other hand, the serum samples treated with guanidine (figure 5) showed high turbidity, giving high values for $A_{1}$ both for the incubated $(0.278 \pm$
$0.089)$ and non incubated $(1.530 \pm 0.085)$ samples when compared with the control assay $(0.143 \pm$ 0.006). The centrifugation at $14,000 \mathrm{rpm}$ was not able to remove the turbidity; therefore, the interference problem in CA samples persisted. The standard curve obtained from these assays, although linear, showed that in heated samples the iron concentration was much lower than the expected value, with an absorption coefficient of $5 \times 10^{-4}(\mu \mathrm{g} / \mathrm{dL})^{-1} \times \mathrm{cm}^{-1}$. Iron concentration in non heated samples fell above the expected, with an absorption coefficient of $2.2 \times 10^{-3}(\mu \mathrm{g} / \mathrm{dL})^{-1} \times \mathrm{cm}^{-1}$.

Absorbance spectrum: Fig 6 shows the absorbance spectrum after the proteolysis and control assays. This profile showed a coincidence of absorbance peaks in the wavelength of $560 \mathrm{~nm}$. This indicated that the treatment did not promote spectrum deviations within the wavelength interval in which absorbance in this assay is measured. 


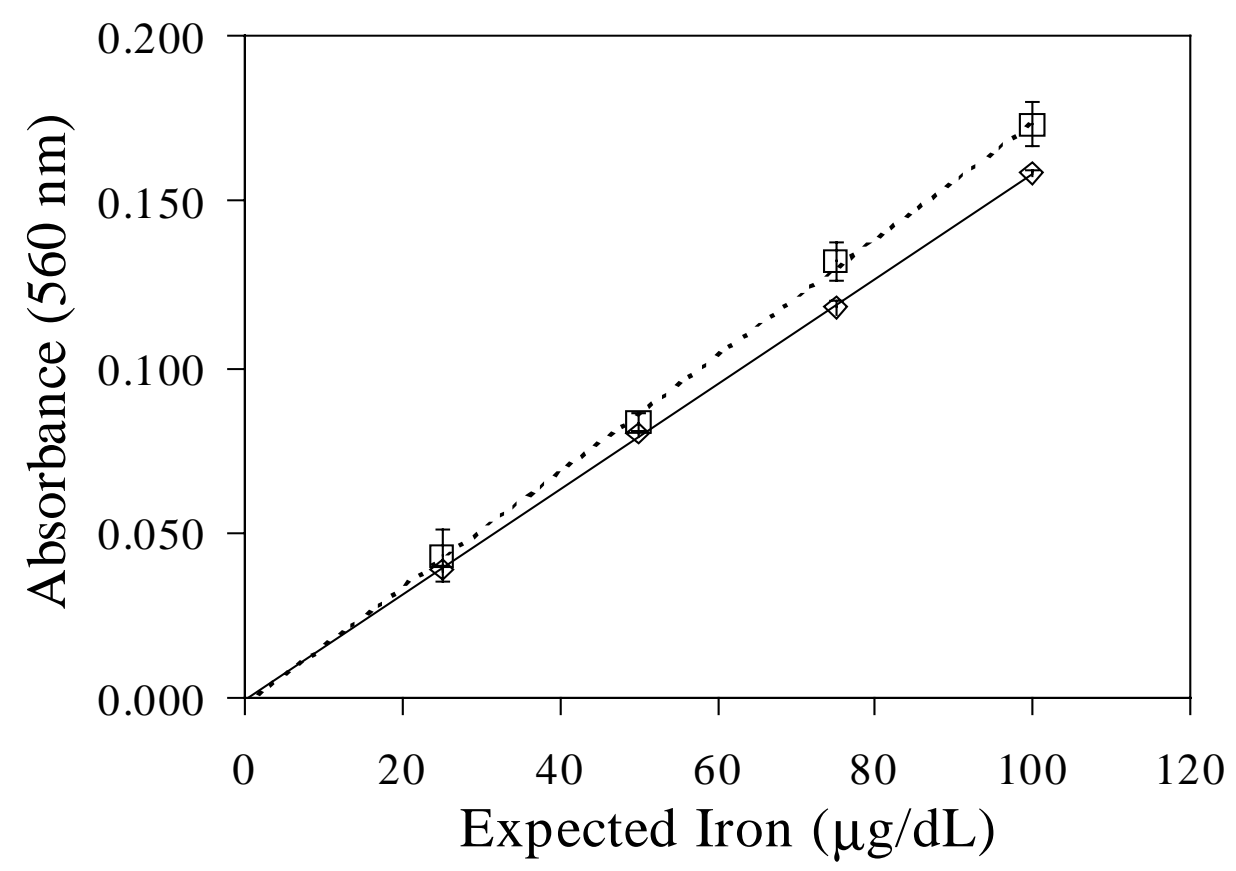

Figure 2 - Iron standard curve from CA serum samples were determined by increasing iron concentrations and its respective mean values $\pm S D(n=2)$ of corrected absorbance $\left(A_{1}\right.$ were subtracted from the respective $\mathrm{A}_{2}$ values and $\Delta \mathrm{A}$ values of serum sample without iron standard solution); the lines were obtained by linear regression of points referring to proteolysis assays, $y=0.0016 x+0.0002, R^{2}=$ 0.9998 (—s_- and control assay, $y=0.0018 x-0.0020, R^{2}=0.9988(--凶--)$.

Iron recovery: The percentage of iron recovery is shown in Fig 7. In the control assay performed with plasma samples it reached $370 \pm 104 \%$, while in the sample submitted to proteolysis this value was $117 \pm 3 \%$, much closer to the expected. With serum samples of cannulated animal, the assays showed a recovery of added iron close to $100 \%$, both for control and modified assay $(108 \pm 2 \%$ and $112 \pm 4 \%$, respectively). In the guanidine assays, an iron recovery percentage of $191 \pm 19 \%$ for non heated and $41 \pm 6 \%$ for heated ones was observed.

\section{DISCUSSION}

All serum samples of cannulated animals produced turbidity without previous proteolysis, when colorimetric assay was used. However, for non cannulated animals, serum samples not present turbidity. 


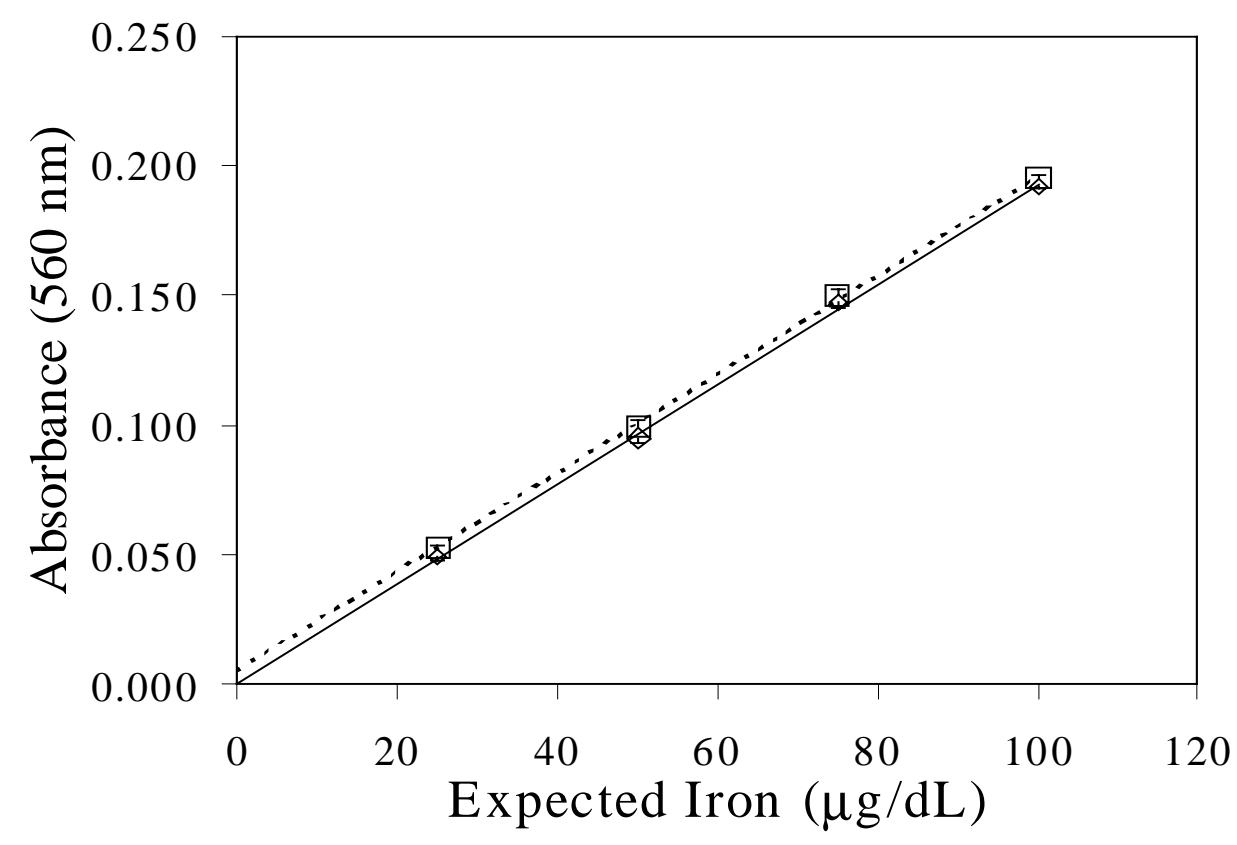

Figure 3 - Iron standard curve obtained from NCA serum samples were determined by increasing iron concentrations and its respective mean values $\pm S D(n=2)$ of corrected absorbance $\left(A_{1}\right.$ values were subtracted from the respective $\mathrm{A}_{2}$ values and $\Delta \mathrm{A}$ values of serum sample without iron standard solution); the lines were obtained by linear regression of points referring to proteolysis assay, $y=0.0019 x+$

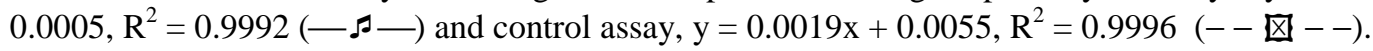

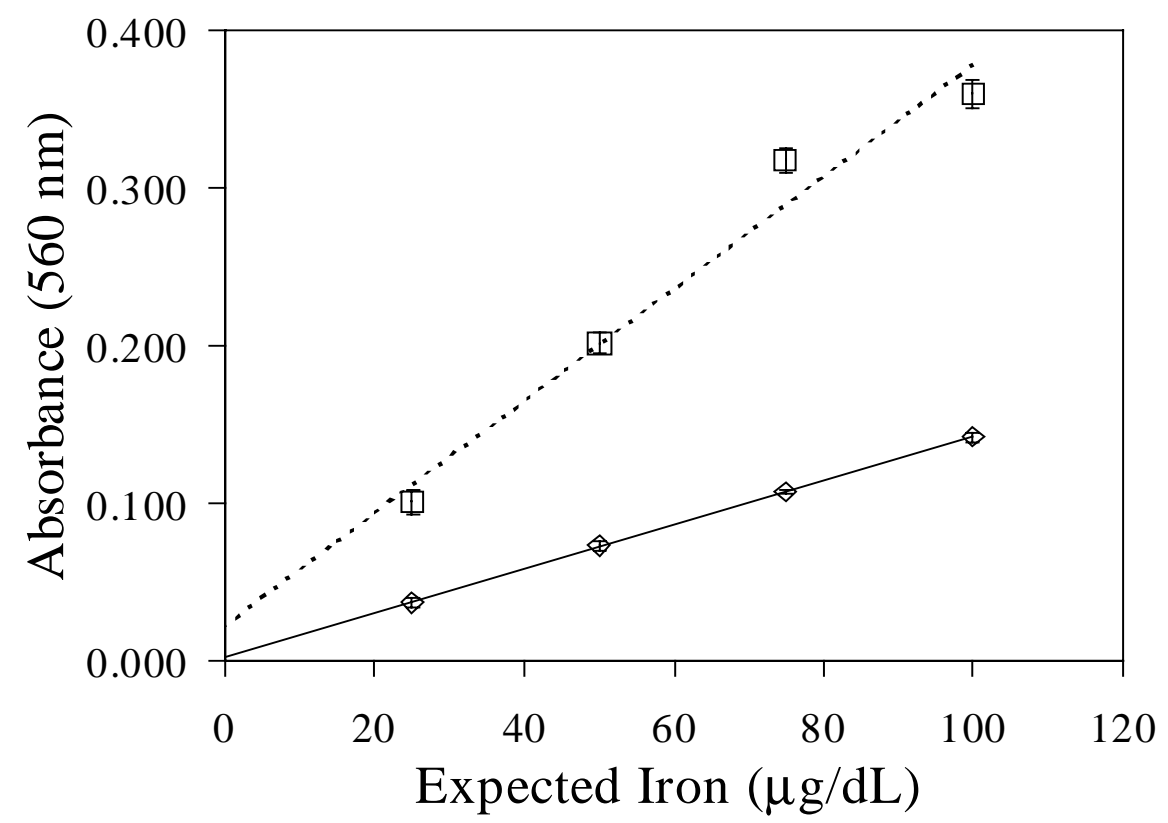

Figure 4 - Iron standard curve obtained from CA plasma samples were determined by increasing iron concentration and its respective mean values $\pm S D(n=2)$ of corrected absorbance $\left(A_{1}\right.$ values subtracted from respective $\mathrm{A}_{2}$ values and $\Delta \mathrm{A}$ values of serum sample without iron standard solution); the lines were obtained by linear regression of proteolysis assay referring points, $\mathrm{y}=0.0014 \mathrm{x}+0.0025, \mathrm{R}^{2}=0.9999$ (一_-) and control assay, $\mathrm{y}=0.0036 \mathrm{x}+0.0220, \mathrm{R}^{2}=0.9692(--\bigotimes--)$. 


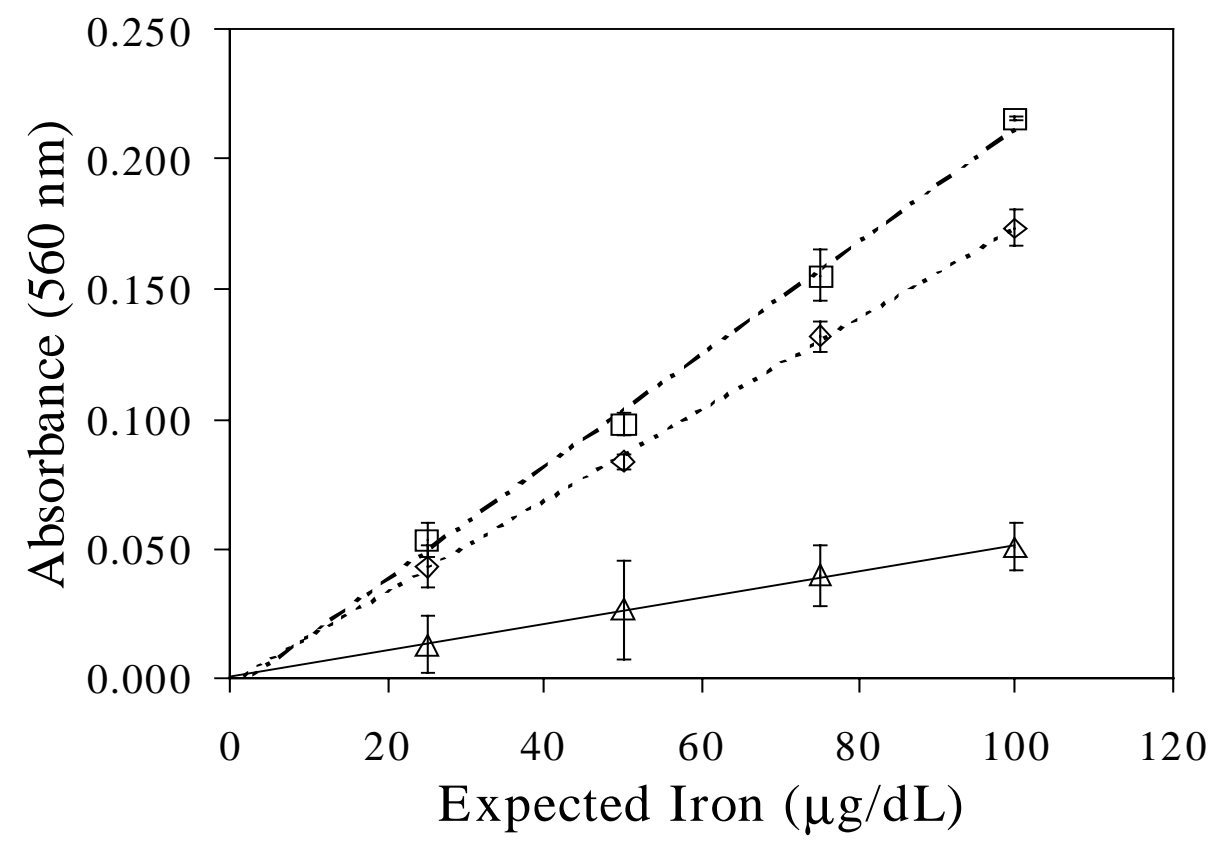

Figure 5 - Iron standard curve from NCA serum samples; after guanidine treatment (1.6 mol/L, final concentration in the mixture), the supernatant was analyzed by iron; lines obtained by linear regression of referring points to assays treated with guanidine and incubated at $37^{\circ} \mathrm{C}, \mathrm{y}=0.0005 \mathrm{x}+0.0010, \mathrm{R}^{2}=$ $0.9979(-\rho-)$, only guanidine treatment, $y=0.0022 x-0.0052, R^{2}=0.9954(-区--)$ and control assay, $\mathrm{y}=0.0018 \mathrm{x}-0.0020, \mathrm{R}^{2}=0.9988(--\mathrm{s}--)$. Indicated points were determined by increasing iron concentration and its respective mean values $\pm S D(n=2)$ for corrected absorbance $\left(A_{1}\right.$ values subtracted from respective $A_{2}$ values and $\Delta \mathrm{A}$ values of serum sample without $100 \mu \mathrm{g} / \mathrm{dL}$ iron standard solution).

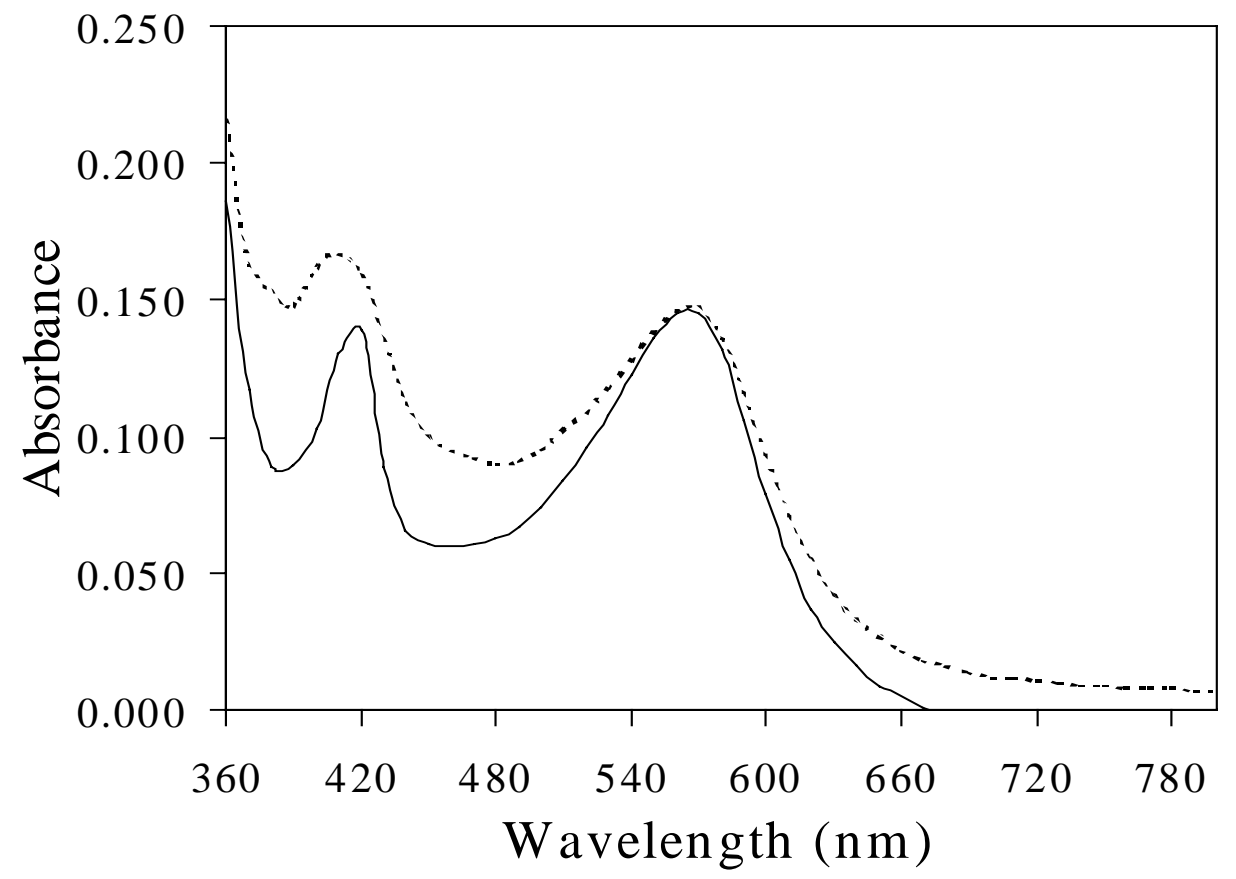

Figure 6 - Spectrum scanning performed with samples of proteolytic $(-)$ and control assays $(---)$; assays with NCA serum pool samples. Scanned interval from $360 \mathrm{~nm}$ to $800 \mathrm{~nm}$. 


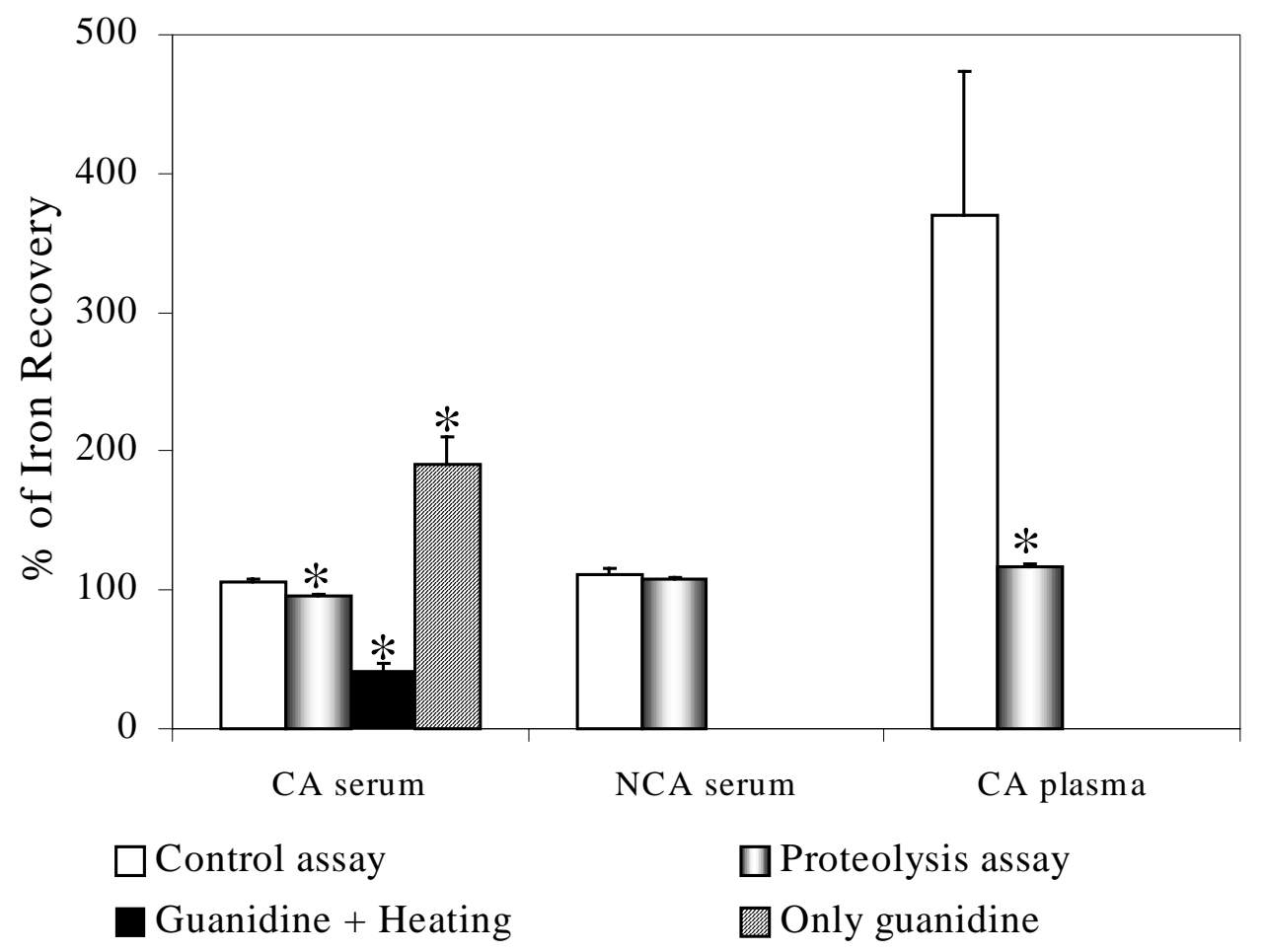

Figure 7 - Recovery rate of iron added to serum samples of cannulated animals (AC Serum), non cannulated animals serum (NCA Serum) and cannulated animals plasma (AC Plasma); columns represent means \pm SD of four measurements that determined iron standard curve for each assay type. AC represents cannulated animals and NCA represents non cannulated animals; significant difference in relation to control assay: $* \mathrm{P}<0.05$.

In consequence, the $\mathrm{A}_{1}$ values were higher in serum CA and plasma samples. Ooi et al (1992) found abnormally increased iron concentrations in serum samples from hemodialysis patients. According to the authors the combination of increased fibrinogen synthesis, commonly seen in renal patients on hemodialysis, and using heparin during the dialysis would lead to the persistence of fibrinogen in serum. On the other hand, the $\mathrm{pH}$ of the iron-dissociating buffer is close enough to the pI of fibrinogen to decrease the solubility of the protein, creating turbidity. However, our results with guanidine treatment was not effective. It is possible that other proteins would appear due to the surgical process. In acute aggressions hepatocytes decrease albumin synthesis and increase $\mathrm{C}$ reactive protein, ceruloplasmin, $\alpha-1$ antitrypsin, transferrin, fibrinogen, haptoglobin components of complement (McPherson, 1996). Furthermore, cannulated animals $\mathrm{A}_{1}$ values observed in the serum were higher than those observed in the plasma (Fig. 1). However, when we analyzed the iron recover results (Fig. 7) we observed a tremendous increase in iron recuperation for plasma compared with the serum. At the end of the assay, the plasma sample-buffer mixture was greater than serum sample-buffer mixture. These results indicated that the turbidity of plasma samples were detained. As a matter of fact, Ooi et al (1992) reported that low heparin concentrations retard fibrinogen precipitation in the mixture buffer/sample.

The assay without previous proteolysis offered restrictions in samples of cannulated animals, essential procedure in our experiments. The removal of proteins from samples by TCA precipitation (Williams et al., 1977) was avoided due to the possibility of co-precipitation of the iron. As proposed by Ooi et al. (1992) the iron determination in serum of cannulated animals after previous treatment with guanidine was tried. Our results showed that this procedure did not avoid the turbidity. Persisting even after the centrifugation. Despite being linear, the curves 
referent of assays did not show coherent absorbance levels for expecting iron concentrations. As a consequence, the iron recovery rates were much higher than expected, due to the medium turbidity, or much lower than the expected due to carrying of iron to the precipitate.

Our results demonstrated that the previous treatment of plasma samples with proteases was effective. In serum samples of cannulated and non cannulated animals, our results also showed good linearity for standard and recovery of external standard curves. The absorbance spectrum showed peak coincidence in the wavelength of interest $(560 \mathrm{~nm})$ assured the quality of the result. The significant reduction of $\mathrm{A}_{1}$ values both in plasma as well as in serum samples permitted the suppression of these auxiliary absorbance readings. Our data also revealed that serum samples of non cannulated animals, without previous enzymatic treatment, showed diminished iron concentration when compared to the treated ones. One possible explanation for these contrast results could be a low auxiliary absorbance values. In conclusion, the enzymatic proteolysis treatment became useful for both plasma and serum of cannulated animals in case of iron determination by colorimetric assays. Besides that our results have shown a decreased of number of steps and lower possibilities of errors due to precipitation interference.

\section{RESUMO}

Descreveu-se modificação no método colorimétrico comercial para dosagem de ferro sérico que utiliza Ferrozine ${ }^{\circledR}$ como reagente de cor. A modificação foi proposta porque durante o procedimento observava-se turvação quando o soro de animais submetidos à cirurgia era utilizado, comprometendo os resultados. Foi acrescentado ao método um tratamento prévio do soro com enzimas proteolíticas. Avaliou-se também a modificação utilizando amostras de plasma, o que não é recomendado na metodologia original. O tratamento das amostras com cloreto de guanidina, descrito anteriormente para amostras de pacientes submetidos à hemodiálise, também foi avaliado. Os resultados demonstraram que: a) tratamento das amostras com tripsina e quimotripsina eliminou a turvação; b) não houve diferenças entre as curvas padrão obtidas pelo método original ou modificado para amostras de soro provenientes de animais controle; c) as absorbâncias das amostras de soro e plasma submetidas à proteólise foram proporcionais às concentrações de ferro, estimada pela adição de diferentes concentrações do íon; d) o tratamento enzimático permitiu a utilização de plasma; e) o tratamento prévio dos soros, de animais submetidos à cirurgia, com guanidina. $\mathrm{HCl}$, não foi eficaz.

\section{REFERENCES}

Bothwell, T. H.; Charlton, R. W. and Cook, J. D. (1979), Measuremente of the plasma iron concentration, In Iron metabolism in man. Oxford: Blackwell Scientific Publication. pp. 353-362.

Chianca-Jr D. A. and Machado B. H. (1994), The sensitivity of the Bezold-Jarisch reflex is increased in rats with sinoaortic deafferentation. Braz J Med Biol Res., 27, 775-781.

McPherson, R. A. (1996), Specific Proteins. InClinical Diagnosis and Management by Laboratory Methods ed. 19 $9^{\text {th }}$ Henry, J. B. W.B.. Saunders Company, Philadelphia. pp. 237-252.

Ooi D. S.; Perkins S. L. and Tokessy, N. E. (1992), Elimination of fibrinogen interference in a dyebinding method for iron. Clin Chem., 38, 541-544.

Stookey, L. L. (1970), Ferrozine - a new spectrophotometric reagent for iron. Anal Chem., 42, 779-782.

Valcour, A. A.; Krzymowski, G.; Onoroski, M.; Bowers Jr., G. N. and McComb, R. B. (1990), Proposed reference method for iron in serum used to evaluate two automated iron methods. Clin Chem., 36, 1789-1792.

Williams, H. L.; Johnson, D. J. and Haut, M. J. (1977), Simultaneous spectrophotometry of $\mathrm{Fe}^{2+}$ and $\mathrm{Cu}^{2+}$ in serum denatured with guanidine hydrochloride. Clin Chem., 23, 237-240. 